\title{
Digital Village in Eye Decentralization: Half-Hearted Implementation of Technology
}

\author{
Wiwit Yuhita Effendi \\ Ministry of Home Affairs of the Republic of Indonesia \\ Institut Pemerintahan Dalam Negeri (IPDN) \\ Sumedang, Republik indonesia
}

\begin{abstract}
The purpose of the study was to determine the condition of the village from the perspective of decentralization with the development that had been implemented by the State. The method used is the use of the Indonesian Village Data Center dataset. The results of this study are that in its implementation, the regulation of the Village has not been able to accommodate all the interests and needs of the village community which until now (Siegel, 1977). It is recommended to conduct further research in decentralization.
\end{abstract}

Keywords:- Village, Implementation and Decentralization.

\section{INTRODUCTION}

In a normative understanding in the Indonesian republic, namely Law 6 of 2014 concerning Villages states that Villages are traditional villages and villages or referred to by other names, hereinafter referred to as Desa, is a legal community unit that has the authority to regulate and manage affairs government, interests of the local community based on community initiatives, original rights, and/or traditional rights that are recognized and respected in the system of government of the Unitary Republic of Indonesia (Tev, 2017).

There is a view In Indonesian territory there are approximately (two hundred and fifty) "Zelfbesturende landschappen" and "Volksgemeenschappen", such as villages in Java and Bali, Nagari in Minangkabau, hamlets, and clans in Palembang, and so on (Kuenzi, 2005). These regions have an Original composition and can, therefore, be considered as special regions (Weare, Musso, \& Jun, 2009). The Republic of Indonesia respects the position of these special regions and all state regulations concerning these regions will commemorate the rights of the origin of these regions (Waites, 2003).

With a background that is that the Village has the right of the origin and traditional rights in regulating and taking care of the interests of the local community and play a role in realizing the ideals of independence based on the 1945 Constitution of the Republic of Indonesia (Davila, 2008). Then that in the course of the Republic of Indonesia, the Village has developed in various forms that need to be protected and empowered to be strong, advanced, independent, and democratic so as to create a strong foundation in carrying out governance and development towards a just, prosperous, and prosperous society. then the
Village in the composition and procedures for governing government and development need to be regulated separately by law (Holman, 1988).

In the history of village regulation, several regulations on villages have been established, namely Law Number 22 of 1948 concerning the Principle of Regional Government, Law Number 1 of 1957 concerning the Principles of Regional Government, Law Number 18 of 1965 concerning Principles Regional Government, Law Number 19 of 1965 concerning (Holman, 1988). Praja Village as a Transitional Form to Accelerate the Establishment of Level III Regions in the Entire Territory of the Republic of Indonesia, Law Number 5 of 1974 concerning Principles of Regional Government, Law Number 5 of 1979 regarding Village Government, Law Number 22 of 1999 concerning Regional Government, and finally by Law Number 32 of 2004 concerning Regional Government (Holman, 1988).

In its implementation, the regulation regarding the village has not been able to accommodate all the interests and needs of the village community, which until now has reached around 73,000 (seventy-three thousand) villages and around 8,000 (eight thousand) wards (Weare et al., 2009). In addition, the implementation of village regulations that have been in effect is no longer in accordance with the times, especially among others concerning the position of customary law communities, democratization, diversity, community participation, as well as development progress and equity, causing disparities between regions, poverty, and socio-cultural issues which can disrupt the integrity of the Unitary Republic of Indonesia (Smolík \& Novák, 2019).

\section{THEORY}

The definition of a village is as a legal community unit that has an original arrangement based on special privileges (Eadeh \& Chang, 2020). The rationale for village governance is diversity, participation, genuine autonomy, democratization and community empowerment (Kolbe, Boos, \& Gurtner, 2005) . According to (Brennan, Carr, \& Cousins, 2007) states the Village in a general sense as: "a phenomenon that is Universal, exists anywhere in the world, as a small community, which is related to certain localities both as a place to stay (permanently) and for the fulfillment of their needs, and especially those that depend on the agricultural sector according to ". 
ISSN No:-2456-2165

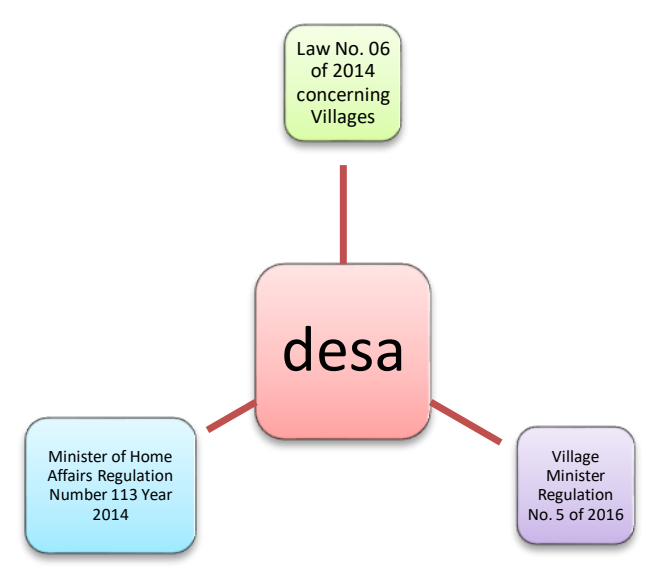

Fig 1:- the relationship between regulations and the village

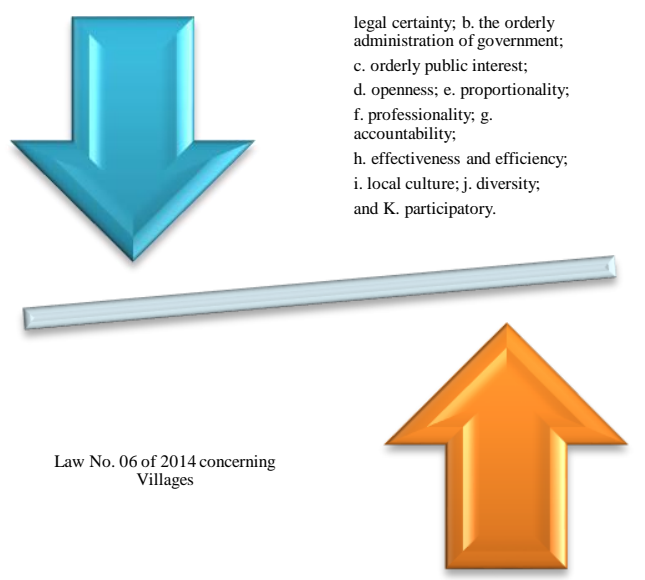

Fig 2:- Providing that the Village Administration is based on principles

Village Government is an extension of the central government which has a strategic role to regulate the people in rural areas in order to realize government development (Rohrer, Egloff, \& Schmukle, 2017). Based on this role, the Regulations or Laws relating to the Village Administration that govern the Village Government will be issued, so that the wheels of government-run optimally. Village Government consists of the Village Head and Village Officials, which includes the Village Secretary and Other Instruments. The organizational structure is as follows:

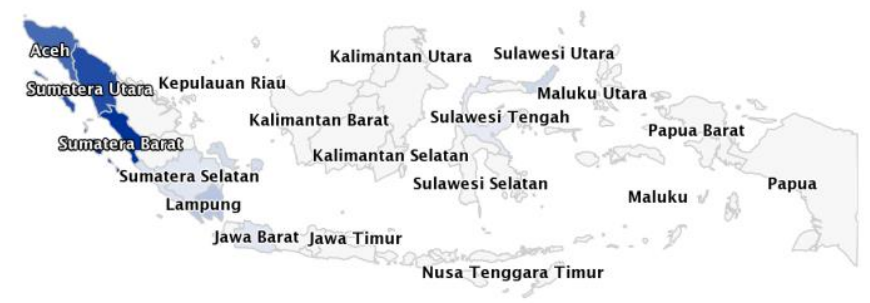

Village Financial Management is the whole activity which includes Planning, Implementation, Administration, Reporting, and Village Financial Accountability (Menegatti \& Rubini, 2013). The implementation of village authority based on original rights and the village-scale local authority is funded by the village budget. The implementation of local scale village authority, besides being funded by the Village Budget, can also be funded by the State Budget and Regional Budget (Henderson, 2010). The exercise of village authority assigned by the Government is funded by the State Budget. The State Budget Revenue and Expenditure Budget is allocated in the portion of the Ministry / Agency's budget and is channeled through the Regency / City Regional Apparatus Work Unit (Hoffman, 2007).

\section{METHODS AND DATA}

This research method uses the Indonesian Village Data Center dataset. In the Indonesian Village Data Center (PDDI), the Village APB administration system is basically divided into revenue management, expenditure, financing, planning, reporting and administering village finances. Village income, in this case, all money received through a village account which is a village right within 1 (one) fiscal year that does not need to be paid back by the village.Village income consists of village's original income or Village PA in the form of business results both from BUMDesa or village treasury land, assets (boat mooring, village market, public baths, irrigation networks), self-help, participation, and mutual cooperation (building with strength) itself which involves community participation in the form of labor, goods valued by money), etc. (original village income is the result of village fees).

Transfers in the form of Village Funds, part of the district/city regional tax revenue and local user fees, Village Fund Allocation, financial assistance from the Provincial APBD (can be general and specific) (Derado, Dergić, \& Međugorac, 2016). If it is specifically managed in the APBDesa but not applied in terms of use (at least $70 \%$ and at most 30\%), financial assistance for Regency / City APBD (can be general and specific. If it is specifically managed in the APBDesa but not applied in the terms of use most a little $70 \%$ and at most 30\%). Other income, namely grants and donations from third parties that are not binding (giving money in the form of third parties) and other legitimate village income (income as a result of collaboration with third parties and company assistance located in the village) (Volkov, 2015). 


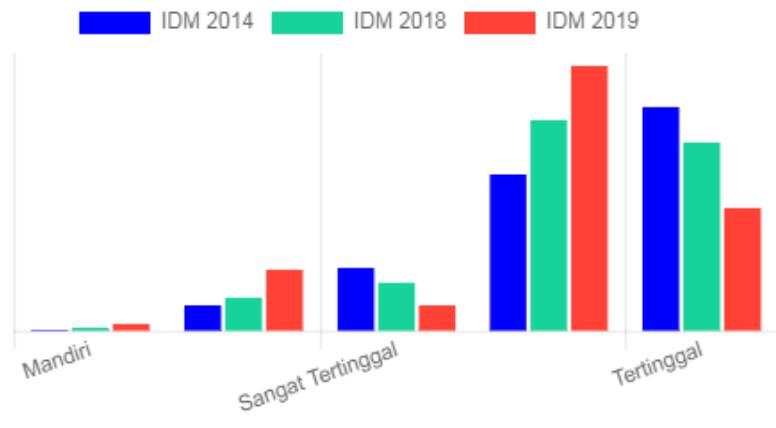

Fig 4:- Mandiri Village Index (IDM)

Source: DITJEN PPMD, Ministry of Villages, PDTT 2019

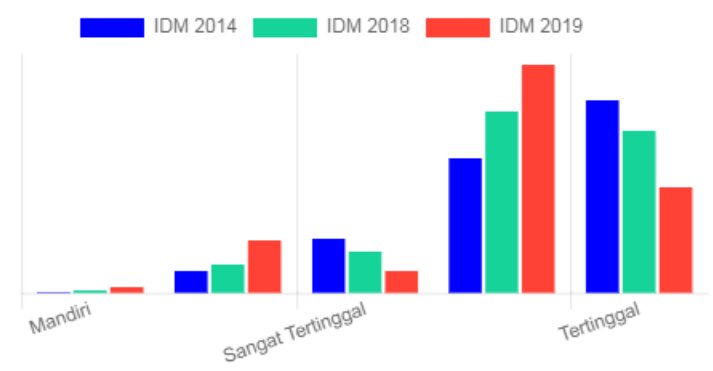

Fig 5:- Village Development Index (IPD)

Source: DITJEN PPMD, Ministry of Villages, PDTT 2019

\section{RESULTS}

Description of Rural Area Development Within the Indonesian Village Data Center (PDDI), based on Article 3 of PDTT Village Minister Regulation No. 5 of 2016, rural area development aims to accelerate and improve the quality of services, economic development, and/or empowerment of rural communities through a participatory approach by integrating various policies, plans, programs, and activities of the parties in the designated area (Tang \& Huhe, 2016). Village Development Arrangements in addition to Law Number 6 the Year 2014 concerning Villages and implementing regulations are Presidential Regulation Number 2 the Year 2015 concerning the National Medium-Term Development Plan for 2015-2019 which is a reference for stakeholders related to Village and Rural Development.

Rural area development is the concept of rural-based development by taking into account the social and cultural characteristics of the people who live in rural areas. Rural communities in general still have and preserve the local wisdom of rural areas that are closely related to social, cultural and geographical characteristics, demographic structure and village institutions (Tang \& Huhe, 2016). Rural development is carried out within the framework of interventions to reduce the level of progress gap between rural and urban areas (urban bias). Rural development is expected to be a solution for social change in rural communities
Rural-based development priorities include (Rohrer et al., 2017):

$>$ Capacity building and mentoring for village government officials and government institutions in a sustainable manner;

$>$ Meeting village minimum service standards in accordance with geographical conditions;

$>$ Poverty alleviation and economic development efforts of rural communities;

$>$ Development of human resources, enhancement of empowerment, and the formation of socio-cultural capital of village communities;

$>$ Sustainable management of natural resources and the environment;

$>$ The economic development of rural areas to encourage rural-urban links; and

$>$ Supervising the implementation of the Village Law in a systematic, consistent and sustainable manner through coordination, facilitation, supervision, and assistance.

Rural Area is a terminology that is used as well as an issue that is regulated by, at least, two statutory regulations, namely Law Number 26 of 2007 concerning Spatial Planning and Law Number 6 of 2014 concerning Villages (Schröter \& Röber, 1997). Within the broader framework, the understanding of rural areas in the two Laws overlaps with the mandate of Law Number 23 of 2014 concerning the Regional Government. Related to Rural Areas General provisions article 1, paragraph (23) of Law No. 26/2007 explains that what is meant by rural areas is areas that have the main activities of agriculture, including the management of natural resources with the arrangement of the function of the area as a place for rural settlements, government services, social services, and economic activities. Law Number 6 of 2014 concerning Villages adopts intact without changing the explanation of rural areas from the explanation of Law No. 6/2007 (Tepe, 2012).

Rural Area Construction according to Law No. 6 of 2014 In the construction of the Village Law, understanding Rural Areas is more sectoral in nature, as stipulated in Article 83 of Law No.6 / 2014, related to (Johnston, 1986);

$>$ Use and use of village areas in the framework of determining development areas in accordance with district/city spatial planning.

$>$ Services performed to improve the welfare of rural communities.

$>$ Infrastructure development, improvement of the rural economy, and development of appropriate technology.

$>$ Empowering rural communities to increase access to services and economic activities.

Furthermore, PDTT Permendes No. 5 years 2016 on the Development of Rural Areas makes it clear that the area that can be designated as a rural area is part of a district/city consisting of several villages bordering on an integrated planning area that has similarities and/or linkages to problems or potential for development. 


\section{CONCLUSIONS}

Village officials should be more socialized in a transparent program to all citizens, and can coordinate wisely by inviting community members to hold village meetings and want to accommodate all ideas or ideas provided by the community, because even members of the community are the object and subject of development As a valuable asset, of course, village officials must be better at managing development by making maximum use of the potential in the village so that development can be realized as planned.

The village head and his officials should be able to work together with community leaders, traditional leaders, as well as religious and youth leaders because after all their presence in the midst of the community is very influential, more or less they have the power and share in community development, and these community leaders should be able to give a good example to citizens by participating because the community tends to imitate and they will feel embarrassed if they do not participate because of a high sense of solidarity.

For village officials and village development institutions, they should be able to carry out the mandate given by the community, by carrying out the development project well as expected, supervision and all parties need to be done to avoid irregularities, but the community must maintain good relations with the authorities this, by removing excessive suspicion (Sánchez \& Ardoy, 2015). Community members are expected to work with the village government in carrying out development because after all the results of development will be felt and used together, so all community members also have responsibilities in the development.

\section{REFERENCES}

[1]. Brennan, F., Carr, D. B., \& Cousins, M. (2007). Pain management: A fundamental human right. Anesthesia and Analgesia, 105(1), 205-221. https://doi.org/10.1213/01.ane.0000268145.52345.55

[2]. Davila, A. (2008). Latino spin: Public image and the whitewashing of race. In Latino Spin: Public Image and the Whitewashing of Race. Retrieved from https://www.scopus.com/inward/record.uri?eid=2s2.084900194863\&partnerID=40\&md5=fc5ac420a3815c3 01ff621b2f1b4740b

[3]. Derado, A., Dergić, V., \& Međugorac, V. (2016). Croatian youth and populism: A mixed methods analysis of the populism "breeding ground" among the youth in the city of Zagreb . Revija Za Sociologiju, 46(2), 141-173. https://doi.org/10.5613/rzs.46.2.2

[4]. Eadeh, F. R., \& Chang, K. K. (2020). Can Threat Increase Support for Liberalism? New Insights Into the Relationship Between Threat and Political Attitudes. Social Psychological and Personality Science, $11(1), \quad 88-96$. https://doi.org/10.1177/1948550618815919
[5]. Henderson, A. (2010). "Small Worlds" as Predictors of General Political Attitudes. Regional and Federal Studies, 20(4-5), 469-485. https://doi.org/10.1080/13597566.2010.523621

[6]. Hoffman, M. (2007). Foucault's politics and bellicosity as a matrix for power relations. Philosophy \& Social Criticism, 33(6), 756-778. https://doi.org/10.1177/0191453707080599

[7]. Holman, C. B. (1988). Farmers and their partisan affiliations. Rural Sociology, 53(4), 487-497. Retrieved from https://www.scopus.com/inward/record.uri?eid=2s2.00024160624\&partnerID=40\&md5=349a3949278144d 4966fecd41afeb8bc

[8]. Johnston, R. J. (1986). Places and votes: The role of location in the creation of political attitudes. Urban Geography, 7(2), 103-117. https://doi.org/10.2747/0272-3638.7.2.103

[9]. Kolbe, M., Boos, M., \& Gurtner, A. (2005). Social identity in times of international conflict. Peace and Conflict, 11(3), 313-336. https://doi.org/10.1207/s15327949pac1103_6

[10]. Kuenzi, M. (2005). The role of nonformal education in promoting democratic attitudes: Findings from Senegal. Democratization, 12(2), 223-243. https://doi.org/10.1080/13510340500069386

[11]. Menegatti, M., \& Rubini, M. (2013). Convincing Similar and Dissimilar Others: The Power of Language Abstraction in Political Communication. Personality and Social Psychology Bulletin, 39(5), 596-607. https://doi.org/10.1177/0146167213479404

[12]. Rohrer, J. M., Egloff, B., \& Schmukle, S. C. (2017). Probing Birth-Order Effects on Narrow Traits Using Specification-Curve Analysis. Psychological Science, 28(12), https://doi.org/10.1177/0956797617723726

[13]. Sánchez, M. J., \& Ardoy, L. N. (2015). The electoral footprints of Spanish nationalism Territorial identification and vote in state-level political parties, 1980-2013 . Revista Internacional de Sociologia, 73(1). https://doi.org/10.3989/ris.2012.02.12

[14]. Schröter, E., \& Röber, M. (1997). Regime Change and Administrative Culture: Role Understandings and Political Attitudes of Top Bureaucrats from East and West Berlin. American Review of Public Administration, 27(2), 107-132. https://doi.org/10.1177/027507409702700201

[15]. Siegel, M. E. (1977). Citizenship education in five massachusetts high schools. Theory and Research in Social Education, 5(2), 31-55. https://doi.org/10.1080/00933104.1977.10506005

[16]. Smolík, J., \& Novák, P. (2019). Roots of the Czechoslovak skinheads: Development, trends and politics. Human Affairs, 29(2), 157-173. https://doi.org/10.1515/humaff-2019-0013

[17]. Tang, M., \& Huhe, N. (2016). The variant effect of decentralization on trust in national and local governments in Asia. Political Studies, 64(1), 216234. https://doi.org/10.1111/1467-9248.12177 
[18]. Tepe, M. (2012). The public/private sector cleavage revisited: The impact of government employment on political attitudes and behaviour in 11 west European countries. Public Administration, 90(1), 230-261. https://doi.org/10.1111/j.1467-9299.2011.01961.x

[19]. Tev, D. (2017). Deputies of the state duma of the VI Convocation: Social-professional sources of recruitment. Ekonomicheskaya Sotsiologiya, 18(5), 82-86. Retrieved from https://www.scopus.com/inward/record.uri?eid=2s2.0$85036559342 \&$ partnerID $=40 \& m d 5=f f 3 c 576 a 3 b 20 d 5 b$ faafa13cdc881b732

[20]. Volkov, S. (2015). The rise of popular antimodernism in Germany: The urban master artisans, 1873-1896. In The Rise of Popular Antimodernism in Germany: The Urban Master Artisans, 1873-1896. Retrieved from https://www.scopus.com/inward/record.uri?eid=2s2.085011779728\&partnerID=40\&md5=dad44540baaa1b 1a078aa839aabca345

[21]. Waites, G. M. H. (2003). Development of methods of male contraception: Impact of the World Health Organization Task Force. Fertility and Sterility, 80(1), 1-15. https://doi.org/10.1016/S0015-0282(03)00577-6

[22]. Weare, C., Musso, J., \& Jun, K.-N. (2009). Cross-talk: The role of homophily and elite bias in civic associations. Social Forces, 88(1), 147-174. https://doi.org/10.1353/sof.0.0227 